\title{
УДК 655.3.022.11
}

\section{ДОСЛІДЖЕННЯ ЯКОСТІ ВІДТВОРЕННЯ ЗОБРАЖЕНЬ У ТРАФАРЕТНОМУ ДРУЦІ}

\author{
А. М. Ковальчук ${ }^{1}$, Н. Д. Лотошинська ${ }^{1}$, Л. Я. Маїк², О. С. Семенова ${ }^{1}$ \\ ${ }^{1}$ НУ «Львівська політехніка, \\ вул. Степана Бандери, 12, Львів, 79013, Україна \\ ${ }^{2}$ Українська академія друкарства, \\ вул. Під Голоском, 19, Львів, 79020, Україна
}

\begin{abstract}
Проаналізовано основні тенденції та перспективи розвитку трафаретного способу друку, зокрема, наведено інформацію щзодо провідних науковців і практиків, які займалися дослідженням трафаретного друку, а також фірм-виробників устаткування для трафаретного друку. Трафаретний друк знаходить дедалі ширше застосування у зв 'язку зі зменшенням тиражів продукиії $i$ появою високопродуктивного трафаретного устаткування. Трафаретний спосіб друку дає змогу отримувати високохудожні відбитки з різними спеціальними ефектами, щзо зумовлено особливістю прочесу друку крізь форму і екрануючим впливом сітки - основи друкарської форми. Можливість регулювання товщини фарби на трафаретному відбитку дає змогу його застосовувати для вирішення різних специифічних завдань, зокрема для друку видань для людей з вадами зору. Також неможливо собі уявити без трафаретного способу друку цілу низку галузей промисловості, де потрібно наносити зображення на предмети складної конфігурації або різні види специфічних матеріалів. До таких галузей можна зарахувати текстильну, легку, фарфорову, керамічну, електронну, меблеву та інші галузі промисловості. Одним з важливих напрямів застосування трафаретного друку є друк на різних видах тканин, зокрема і готових виробах (футболки, бейсболки, кепки, куртки, прапори, вимпели, сумки, спортивна форма). Тому проведено дослідження різних видів тканин (бавовна, футер, фланель) водними і пластизольними фарбами. Досліджено основні чинники трафаретного друку, щзо впливають на якість відбитків, тиражестійкість, продуктивність та економічність прочесу. А також визначено основні друкарсько-технологічні параметри трафаретних фарб та задруковуваних матеріалів, що суттево впливають на якість відбитків. Надано практичні рекомендації щуодо друку пластизольними і водними фарбами на різних видах тканин.

Ключові слова: трафаретний друк, водні фарби, пластизольні фарби, стійкість фарбового шару до відмарювання і стирання, метод прискореного старіння, спектрфотометричний метод, адгезійний метод.
\end{abstract}

Постановка проблеми. Серед українських друкарень малого обсягу виробництва у сегменті друкованої реклами трафаретний спосіб друку займає провідне місце 
(рис. 1). Розвиток трафаретного друку пов’язаний з його технологічною гнучкістю: широкий спектр застосування - друкування від малотиражної малоформатної до високопродуктивної великоформатної промислової продукції на різних типах задруковуваної поверхні - папері, картоні, гофрокартоні, текстилю, кераміці, синтетичних матеріалах, металі, склі тощо; простота виготовлення трафаретних форм; невеликий тиск друку; значна товщина шару фарби/лаку; можливість друкування на матеріалі різної геометричної форми [1-10].

Хоча трафаретний спосіб поступається офсетному швидкістю друку та якістю відтворення високолініатурних зображень (не відтворює тонові та багатофарбові зображення, особливо у глибоких тінях), але застосування удосконалених технологій кольороподілу, копіювальних шарів та методів їх обробки, нових видів сіток сприяє розширенню сфери його використання: 45 \% - промислові товари (друкована електроніка, декороване скло та кераміка, деталі автомобілів, паковання); 35 \% — друк по рулонному текстилю та друк на одязі; 20 \% — POS-вироби, зовнішня та внутрішня рекламна продукція тощо $[11,12]$.

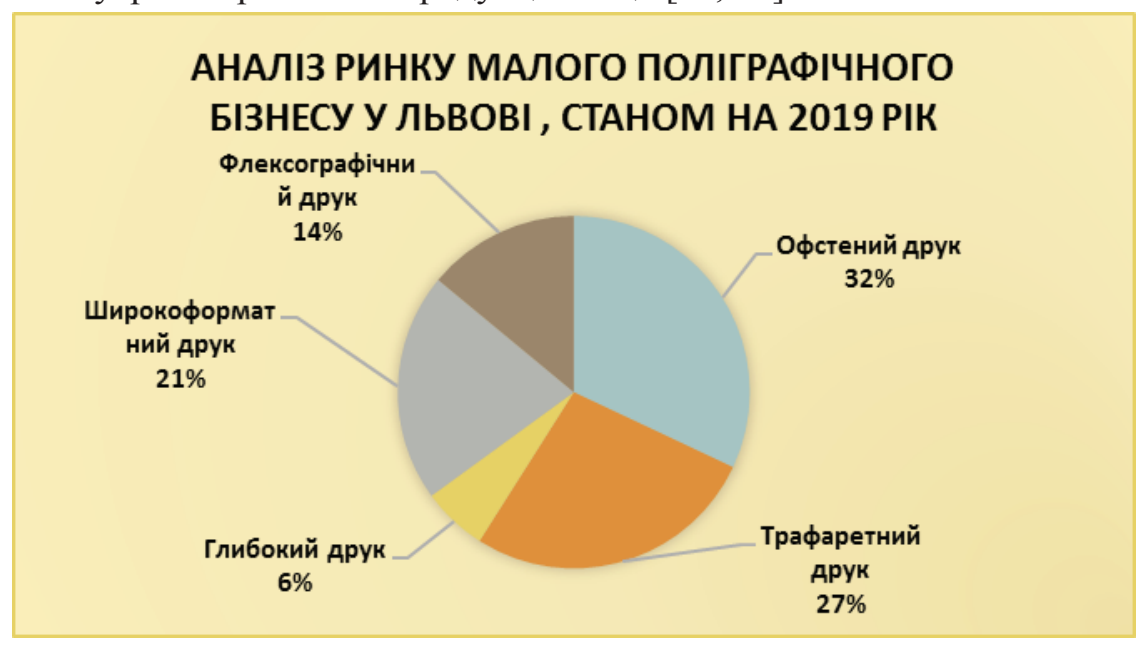

Рис. 1. Сфери використання різних способів друку у сегменті друкованої реклами

Сфера трафаретного друку стрімко розвивається, але прогресу у контролі за якістю віддрукованого матеріалу так і не відбулося. Наразі немає єдиного стандарту, який би підходив для будь-якої фарби та будь-якого обладнання, а ще треба враховувати тип матеріалу на якому друкується, друкарську форму тощо.

Аналіз останніх досліджень та публікацій. Основними і найбільш вагомими джерелами для дослідження були праці таких вчених, як В. В. Дмитрук, А. А. Федулова, С. В. Ромат, Л. Бове Кортленд, Уільям Ф. Арене, А. Пейскенс, Scott O. Fresener, Helen Walters, Joli Ballew, Cindy Brown, J. I. Biegeleisen, Annie Stromquist, Mathilda V. Schwalbach, James A. Schwalbach, а також праці спеціалістів з таких компаній-виробників друкарського обладнання, як AGK, KBA, Heidelberg, MAN Roland, GOSS. У цих працях викладено основи трафаретного друку, детально описано технологія та матеріали, які використовуються у формних і друкарських процесах. 
Дослідження налагодження технологічного процесу і взаємозв'язків між усіма ланками виробництва та розрахунок економічної частини технології - основні проблеми будь-якого трафаретного виробництва. Тому актуальність цієї публікації полягає у тому, щоб експериментальними дослідженнями виробити принципи контролю за якістю віддрукованого матеріалу, що значно оптимізує роботу виробництва та позитивно відобразиться на часі виконання замовлення і якості віддрукованих відбитків.

Мета статті - здійснити аналіз впливу технологічних факторів на якість відтворення зображень на відбитках трафаретного друку.

Виклад основного матеріалу дослідження. Трафаретний друк застосовується для великої кількості матеріалів та виробів. Зображення створюється динамічним за кольором, що пов' язано загалом з товщиною фарбового шару. Система трафаретних друкарських технологій використовується для більшості задрукованих матеріалів, різних за природою і товщиною. Трафаретним способом, як відомо, задруковують фактично будь-яку поверхню - від паперу і пластику до дерева та скла. Розвиток ринку друкованої реклами в останні десятиріччя сприяв розвитку ринку трафаретного друку. Лакування великих та малих форматів, лакування з нанесенням товстих шарів різних за складом лаків - преваги трафарету. Обкладинки багатьох глянцевих журналів зазвичай також лакуються трафаретним способом.

Відновилася зацікавленість до трафарету і у підприємств електронної промисловості, зокрема друк панелей приладів. Виробники сувенірної продукції активно використовують трафаретний друк під час виготовлення деколів.

Трафаретний друк займає лише невеликий сегмент ринку друку, але водночас йому властива велика різноманітність галузей застосування. Розподіл трафаретної продукції по сегментах ринку, у яких використовується трафаретний друк, подано у табл. 1.

Таблиця 1

\section{Сегменти ринку поліграфічних технологій}

\begin{tabular}{|l|l|}
\hline \multicolumn{1}{|c|}{ Сегмент ринку } & \multicolumn{1}{c|}{ Трафаретна продукція } \\
\hline Бізнес-друк & Візитки, бланки, конверти, відкритки, папки, стікери, вивіски \\
\hline Рекламна продукція & Рекламні плакати, банери, постери \\
\hline Одяг і тканини & $\begin{array}{l}\text { Футболки, бейсболки, кепки, куртки, рушники та інші види } \\
\text { текстилю }\end{array}$ \\
\hline Спортивна продукція & Прапори, вимпели, сумки, спортивна форма \\
\hline Продукція для дому & Настінні покриття, що імітують деревину, полімерні матеріали \\
\hline Художня продукція & Колекційні відбитки, друк на декоративній кераміці \\
\hline
\end{tabular}

3 впровадженням нових технологій і фарб спектр задруковуваних матеріалів постійно розширюється, нові машини дають змогу значно збільшити обсяг продукції, що випускається, і підвищити якість друку [5].

Трафаретний друк і надалі буде актуальним як у великих, так і в середніх містах України, наприклад у Києві, Львові, Хмельницькому, Вінниці, Ужгороді та 
багатьох інших. Але більшість регіональних і малих поліграфічних підприємств не має лабораторій вхідного контролю матеріалів, де можна було б провести аналіз відповідності застосовуваних матеріалів і друкарських фарб один одному.

Для того щоб бути впевненим, що трафаретний друк на новому матеріалі (синтетичному або натуральному) буде якісним, а фарба буде триматись на ньому тривалий час, необхідно провести експериментальні дослідження друкарсько-технологічних характеристик. Для експерименту взято відбитки, віддруковані на різних видах матеріалів пластизольними та водними фарбами. Для досліду використовувався друкарський верстат карусельного типу Heidelberg та було вибрано три типи тканин:

- Cotton (100\% бавовна);

- Футер;

- Фланель.

Такий вибір зумовлений тим, що ці тканини є найбільш вживаними на кожному поліграфічному виробництві.

Бавовна є одним з недорогих і поширених матеріалів. Водночас бавовна найважливіший продукт текстильної промисловості, який застосовується під час пошиття одягу, виготовлення меблів, а також у багатьох інших галузях. Також бавовна - це 80 \% усіх футболок, а саме футболки є основними матеріалами для нанесення зображень трафаретним друком.

Одна $з$ найбільш делікатних і приємних для тіла тканин - футер. Це натуральна бавовняна тканина, гладка зі зовнішньої сторони, м'яка і ніжна - 3 внутрішньої, завдяки чому є комфортною. Такі якості вона має завдяки особливому переплетенню ниток полотна під час виробництва. 3 виворітного боку за допомогою петельних протяжок фужерні нитки прикріплюються до основи полотна, внаслідок чого утворюється своєрідна виворітна фактурність.

Фланель - бавовняна, найчастіше синтетична, напівсинтетична тканина полотняного або саржевого переплетення з пухнастим двостороннім або одностороннім рівномірним ворсом.

Для досліду використовували пластизольні фарби Union Ink (ENGLAND), а саме фарби серії 45 782, призначені для друку на будь-яких пористих матеріалах, стійких до короткочасної дії високої (143-166 $\left.{ }^{\circ} \mathrm{C}\right)$ температури під час висушування відбитків.

Фарби на водній основі другі за частотою використання у трафаретному друці, перше місце займають пластизольні. Водні фарби для друку на текстилі набули поширення в текстильній промисловості завдяки тому, що вони найбільш екологічні порівняно з іншими видами фарб для друку на одязі. 3 цієї причини саме фарби на водній основі використовуються під час друку на дитячому одязі, білизні та на інших видах продукції, де екологічна складова є найважливішим параметром. Для досліду були вибрані фарби виробника Union INK (ENGLAND).

Найважливішими технологічними властивостями трафаретних фарб, що визначають їх поведінку в процесі друку і якість відбитка, є молекулярна природа і структурно механічні властивості. Від молекулярно-поверхневих властивостей фарби залежить їх здатність змочувати і прилипати до поверхні форми, ракеля задруковуваного матеріалу. Працездатність системи, іï ефективність залежать від 
структурно-механічних властивостей (в'язкості, пластичності, еластичності) фарби, сумісності складових фарби з копіювальним шаром друкарської форми, дисперсності пігменту [6].

Тому, враховуючи все вищесказане, для перевірки друкарсько-технічних характеристик відбитків трафаретного друку здійснено візуальну та інструментальну оцінку показників якості відбитків трафаретного друку за допомогою сучасних методик дослідження та приладів. Проводилося дослідження стійкості фарбового шару до відмарювання і стирання, стійкість відбитків до лужного середовища. Використовувався метод прискореного старіння та його оцінка спектрофотометричним методом, а також проводилося дослідження адгезії відбитків.

У фарбах для трафаретного друку адгезія залежить від молекулярної природи дукарської фарби і властивостей задруковуваної поверхні. Як видно із результатів дослідження (рис. 2, 3), стійкість до відмарювання та до механічного стирання вища у пластизольних фарбах на різних матеріалах, що можна пояснити тим, що до складу пластизолі входять добавки співполімерів вінілхлориду, стабілізатори та інші добавки, що поліпшують властивості покриття шару фарби.

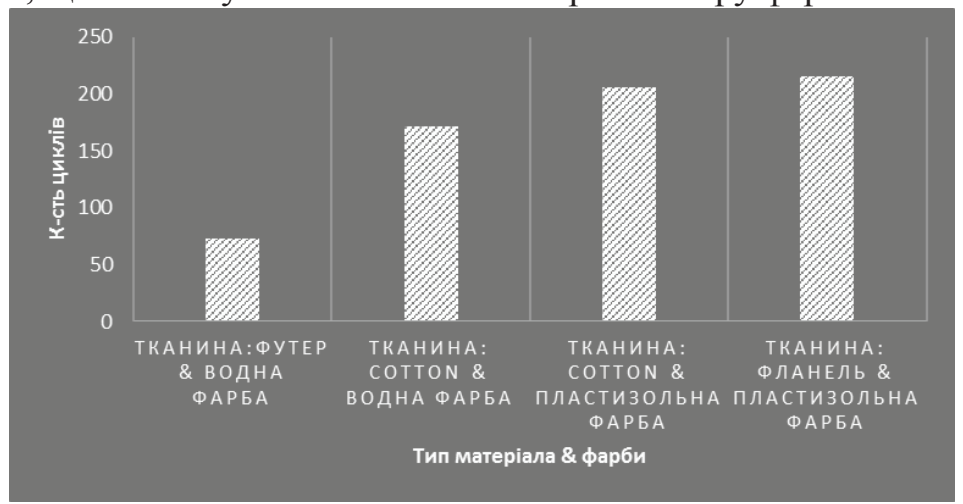

Рис. 2. Показники стійкості до відмарювання відбитків трафаретного друку

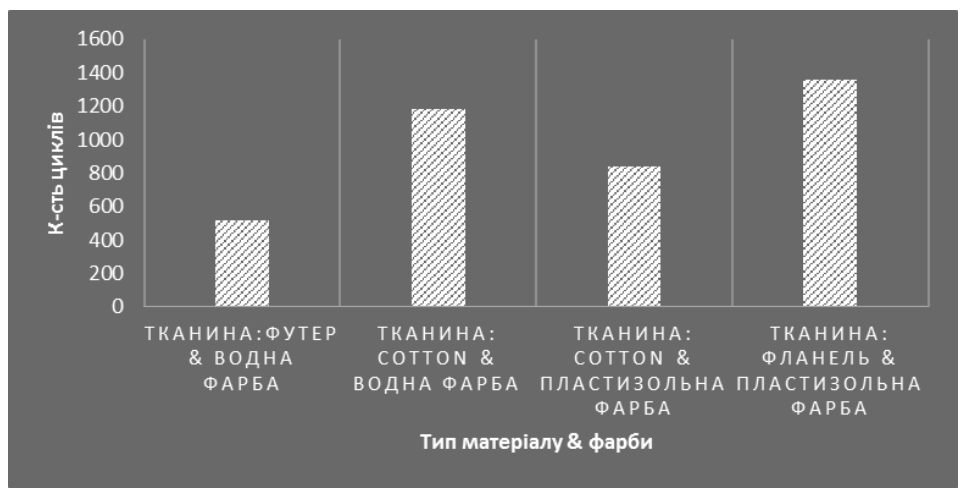

Рис. 3. Показники стійкості до стирання відбитків трафаретного друку

Відносно добрі показники стійкості до механічного стирання водної фарби, нанесеної на тканину котон «100 \% бавовна». Результат повністю відповідає 
очікуванням і твердженням з боку виробника. Структура тканини котон не така щільна як у синтетичних тканинах та має вигляд переплетіння сітки. Завдяки цьому водна фарба з легкістю проникає у тканину і закріплюється на їі волокнах.

Дані досліджень підтверджені зробленими мікрофотографіями поверхні тканини і нанесеними друкарськими фарбами до і після стирання (рис. 4). Водна фарба повністю стирається з волокон тканини, що підтверджується також мікрофотографією перерізу відбитків (рис. 5), де видно, що водна фарба на футері не проникає у структуру тканини, а знаходиться на поверхні, що сприяє швидкому стиранню.

\section{Тканина футер разом з червоною водною фарбою}

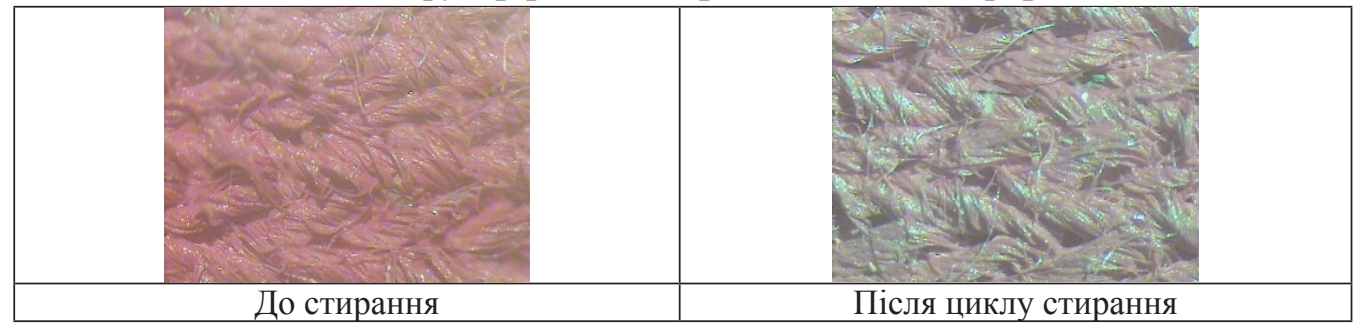

Тканина котон «100 \% бавовна» 3 водною жовтою фарбою

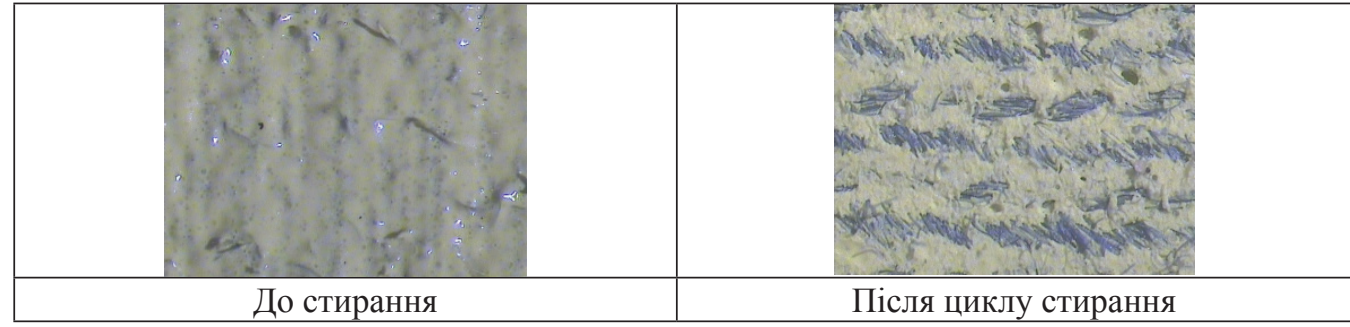

Тканина котон «100 \% бавовна» 3 пластизольною червоною фарбою

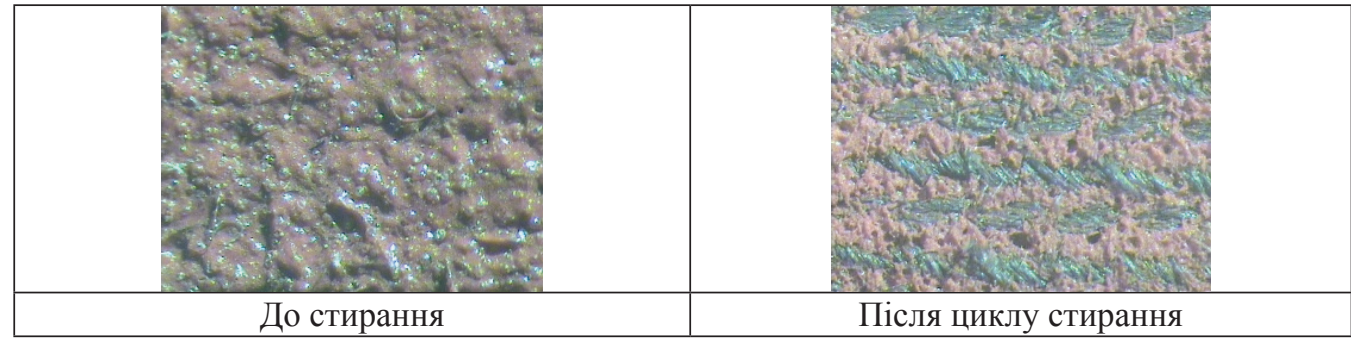

Тканина фланель 3 пластизольною жовтою фарбою

\begin{tabular}{|c|c|}
\hline M. & \\
& \\
\hline До стирання & \\
\hline
\end{tabular}

Рис. 4. Мікрофотографії поверхні тканин 


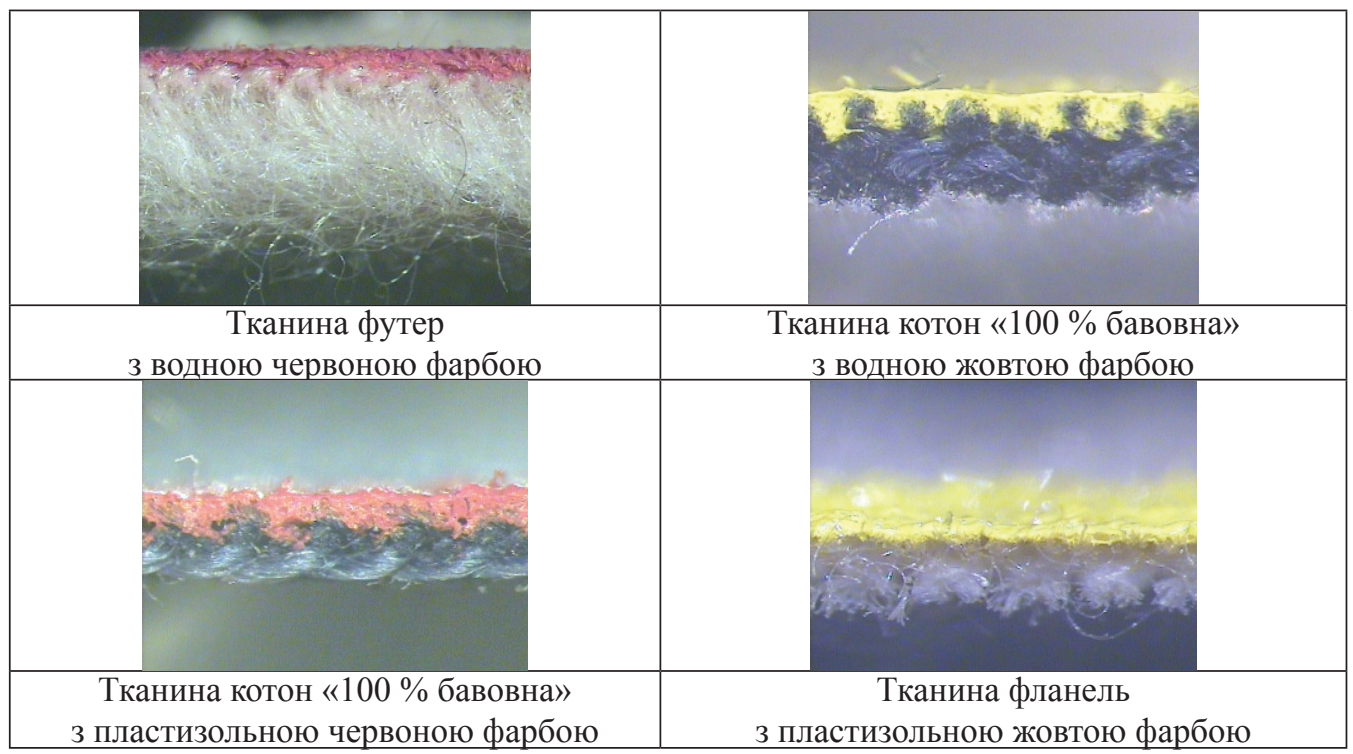

Рис. 5. Мікрофотографії відбитків у розрізі

Водними трафаретними фарбами проводиться друк на синтетиці і натуральних тканинах. Недоліком цих фарб є те, що фарби сильніше від пластизолів схильні до стирання. Але потрібно врахувати, що тести проводились в жорстких умовах, тобто температура розчину була доведена до $90{ }^{\circ} \mathrm{C}$, а агресивна дія лужного середовища прискорює руйнування фарбового шару. У реальних умовах речі з флісу стираються доволі рідко, а рекомендована температура прання не перевищує $30^{\circ} \mathrm{C}$.

Використовувався метод прискореного старіння матеріалів та їх оцінка спектрофотометричними засобами контролю. Пластизольна фарба добре проявила себе і виправдала всі тести, крім вигорання, хоча пораховані за формулами значення відповідають використанню речей приблизно на 3-4 роки, що робить їі придатною для ринку.

Щодо використання водних фарб на футері, то тут необхідно зазначити, що саме через високу щільність волокон його не рекомендується використовувати під час друку фарбами на водній основі, адже фарби не можуть взаємодіяти з внутрішнім шаром тканини і проникають відносно не глибоко, чим зумовлено їхній низький коефіцієнт стійкості. Використання ж пластизольних фарб неможливе на цьому матеріалі, адже для закріплення фарби на тканині потрібно піддати їі термообробці $140{ }^{\circ} \mathrm{C}$ протягом 30-45 с, під час такої обробки тканина сплавиться, адже температурний максимум для неї в межах $90^{\circ} \mathrm{C}$. Тому єдиним варіантом є використання водних фарб на цьому популярному у друці матеріалі. Для цього рекомендовано наносити водну фарбу двома шарами, щоб, як в аналогічної пластизольної фарби, робити своєрідну підкладку. Дати висохнути фарбі протягом 10-15 хв, а потім наносити наступний ідентичний шар. Такий механізм подвійного нанесення шару фарби сприяє більшій стійкості до відмарювання і стирання, що і підтверджено лабораторними дослідженнями (рис. 6). 


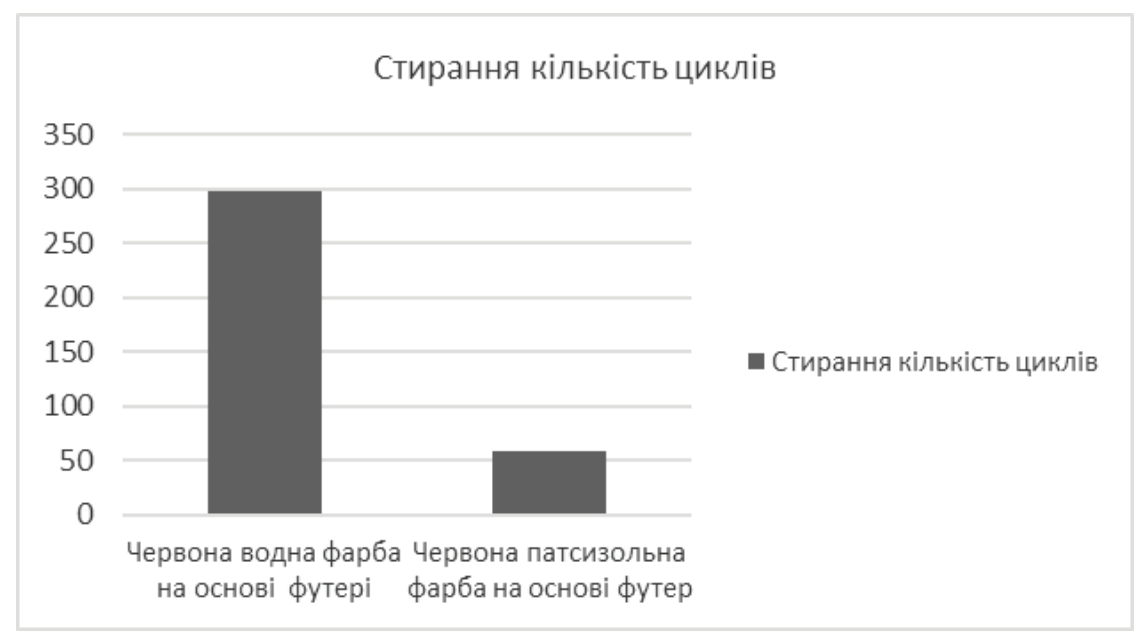

Рис. 6. Порівняння показників стійкості до стирання відбитків водної фарби (з подвійним нанесенням) і пластизольної фарб на футері

Отже, структура відбитку пластизольної фарби на тканині футер почала руйнування на 57-му циклі, що приблизно дорівнює трьохмісячному активному використанню речі. Що стосується водної фарби, то відбиток пройшов тест. Руйнування відбулося на 291-му циклі, сміливо можна стверджувати, що запропонований метод двошарового покриття перевірений в реальних умовах і придатний до використання. У планах це дасть змогу використовувати водну фарбу для друку на утеплених тканинах.

Висновки. У статті досліджено основні друкарсько-технологічні параметри трафаретних фарб та задруковуваних матеріалів, що суттєво впливають на якість отриманих відбитків. Для дослідження вибрано фарби на водній основі та пластизольні трафаретні фарби. Важливим чинником, що впливає на якість відтворення графічної інформації, є структура задруковуваної поверхні. Попри те, що трафаретний друк не вибагливий до задруковуваного матеріалу, однак змочуваність поверхні та всотувальна здатність матеріалу має значний влив на якість відтворюваного зображення. Здійснено візуальну та інструментальну оцінку показників якості відбитків трафаретного друку за допомогою сучасних методик дослідження та приладів.

Згідно із результатами проведених досліджень щодо умов і асортименту застосування поліграфічних матеріалів для оптимізації процесу виготовлення якісної продукції трафаретним способом, можна дати такі рекомендації:

- контролювати якість витратних матеріалів та сировини;

- домагатися найбільш повної відповідності налаштувань поліграфічного обладнання паспортним даним;

- домагатися більш повної стандартизації виробничих процесів на основі постійного приладового та візуального контролю і при використанні оптимальних поєднань основних технологічних матеріалів; 
- для друку на синтетичномістких тканинах, ступінь термообробки яких перевищує $140{ }^{\circ} \mathrm{C}$, використовувати пластизольні фарби.

- лабораторні дослідження відбитків водної і пластизольної фарби дали змогу виявити, що використання водної фарби під час друку тиражів на утеплених тканинах «безпечно» за незначного вдосконалення технології. Суть принципу полягає в тому, що наносити водну фарбу потрібно двома шарами, давати час першому шару засохнути і закріпитись 3 волокном тканини.

\section{СПИСОК ВИКОРИСТАНИХ ДЖЕРЕЛ}

1. Ткачук М. П. Трафаретний друк. Київ : ХаГар, 2000. 264 с.

2. Настоящее и будущее трафаретной печати. URL: http://pechatnick.com/articles/nastoyashee_i_bydyshee_trafaretnoi_pechati.

3. Технологические инструкции по трафаретному способу печати / Тремут В. М., Щепеленков Е. Г. и др. Киев : Техника, 1976. 104 с.

4. Бригінець Л. Товщина фарбової плівки на відбитках трафаретного друку. Друкарство. 2002. № 4. C. 68-70.

5. Chlghoumi-Hasenklever A. Techniken des Textiltransferdrucks. Serigraphis / Siebdruck Praxis. 1995. № 2. C. 48-61; № 3. C. 62-74; № 6. S. 58-74.

6. Der Siebdruck in der Keramik. Siebdruck Praxis. 1991. № 5. S. 28-30.

7. Urban H. Das Plakat. Serigraphis / Siebdruck Praxis. 1994. № 1-6. S.14-36.

8. Urban H. Scotchprint ein revolutionares Herstellungsverfahren fur gro formatige Farbbilder. Serigraphis / Siebdruck Praxis. 1992. № 5. S. 27.

9. Bezem P. Eine zeitgema e Alternative fur die Herstellung gro formatiger Druke. Serigraphis / Siebdruck Praxis. 1995. № 6/1996. № 1. S. 12-16.

10. Peyskens A. La Serigrafia. Tecnica di preparazione della matrice. SAATI S.p.a. Divisione Serigrafia, Appiano Gentile. Como, Italia, 1991. $152 \mathrm{s.}$

11. Сучасні тенденції розвитку поліграфії в Україні. URL: https://ultradruk.com/ tendentsiirazvitiya-rynka-poligrafii-v-ukraine.html.

12. Маїк В. 3., Харів М. С. Аналіз впливу технологічних факторів на якість рельєфних зображень на відбитках трафаретного друку. Квалілогія книги. 2014. № 1 (25). С. 17-21.

\section{REFERENCES}

1. Tkachuk, M. P. (2000). Trafaretnyi druk. Kyiv : KhaHar (in Ukrainian).

2. Nastoiashchee y budushchee trafaretnoi pechaty. Retrieved from http://pechatnick.com/articles/nastoyashee_i_bydyshee_trafaretnoi_pechati (in Russian).

3. Tremut, V. M., \& Shchepelenkov, E. H. y dr. (1976). Tekhnolohycheskye ynstruktsyy po trafaretnomu sposobu pechaty. Kyev : Tekhnyka (in Russian).

4. Bryhinets, L. (2002). Tovshchyna farbovoi plivky na vidbytkakh trafaretnoho druku: Drukarstvo, 4, 68-70 (in Ukrainian).

5. Chlghoumi-Hasenklever, A. (1995). Techniken des Textiltransferdrucks: Serigraphis / Siebdruck Praxis, 2, 48-61 ; 3, 62-74 ; 6, 58-74 (in German).

6. Der Siebdruck in der Keramik. (1991): Siebdruck Praxis, 5, 28-30 (in German).

7. Urban, H. (1994). Das Plakat: Serigraphis / Siebdruck Praxis, 1-6, 14-36 (in German). 
8. Urban, H. (1992). Scotchprint ein revolutionares Herstellungsverfahren fur gro formatige Farbbilder: Serigraphis / Siebdruck Praxis, 5, 27 (in German).

9. Bezem, P. (1995). Eine zeitgema e Alternative fur die Herstellung gro formatiger Druke: Serigraphis / Siebdruck Praxis, 6/1996, 1, 12-16 (in German).

10. Peyskens, A. (1991). La Serigrafia. Tecnica di preparazione della matrice. SAATI S.p.a. Divisione Serigrafia, Appiano Gentile. Como, Italia (in Italian).

11. Suchasni tendentsii rozvytku polihrafii v Ukraini. Retrieved from https://ultradruk.com/ tendentsii-razvitiya-rynka-poligrafii-v-ukraine.html (in Ukrainian).

12. Mayik, V. Z., \& Khariv, M. S. (2014). Analiz vplyvu tekhnolohichnykh faktoriv na yakist reliefnykh zobrazhen na vidbytkakh trafaretnoho druku: Kvalilohiia knyhy, 1 (25), 17-21 (in Ukrainian).

doi: 10.32403/0554-4866-2020-1-79-78-88

\title{
RESEARCH ON REPRODUCTION QUALITY OF IMAGES IN SCREEN PRINTING METHOD
}

\author{
A. M. Kovalchuk ${ }^{1}$, N. D. Lotoshynska ${ }^{1}$, L. Y. Mayik ${ }^{2}$, O. Y. Semenova ${ }^{1}$ \\ ${ }^{1}$ Lviv Polytechnic National University, \\ 12, Bandera St., Lviv, 79013, Ukraine \\ ${ }^{2}$ Ukrainian Academy of Printing, \\ 19, Pid Holoskom St., Lviv, 79020, Ukraine \\ natlot@ukr.net
}

The basic tendencies and prospects of development of screen printing method have been analysed, in particular, summary information about leading researchers and practitioners engaged in the research of screen printing method, as well as manufacturers of screen printing equipment. Screen printing method is becoming more widely used due to the decrease of products edition and the advent of high-performance screen printing equipment. Screen printing method allows highly artistic imprints with various special effects due to the peculiarity of printing process through the plate and screening effect of grid - basics of the printing plate. The ability to adjust the ink thickness on the stencil print allows its use for various specific tasks, in particular the print media for the visually impaired. It is also impossible to imagine a number of industries without screen printing method where you need to apply images to complex configuration objects or different types of specific materials. Such industries include textile, light, porcelain, ceramic, electronic, furniture and other industries. One of the important areas of screen printing application is the printing on different types of fabrics, including finished products (T-shirts, caps, hats, jackets, flags, pennants, bags, athletic form). Therefore, the study has been carried out on different types of fabrics (cotton, footer, flannel) with water and plastisol inks. The basic screen printing factors that affect the quality of imprints are: circulation, productivity and 
efficiency of the process. In addition, the basic printing and technological parameters of screen printing inks and printed materials, which have a significant impact on the quality of imprints, are defined. Practical recommendations for printing with plastisol and water inks on different types of fabrics are given.

Keywords: screen printing method, water paints, plastisol inks, resistance of the ink layer to scaling and abrasion, method of accelerated aging, spectrophotometric method, adhesive method.

Стаття надійшла до редакиії 27.03.2020.

Received 27.03.2020. 